\title{
Occupational Structure and Labor Market Change in Western Europe since I990
}

\author{
Daniel Oesch
}

Observers of social change have been fascinated for a long time by the question of how the employment structure evolves: toward good jobs, bad jobs, or increasing polarization? Three issues are at stake. At the microlevel of single jobs, the concern is with the quality of new employment created. The question raised is to know whether jobs are becoming better paid, more highly skilled, and endowed with greater autonomy. At the macrolevel of social structure, the debate evolves around the question whether occupational change transforms affluent countries into large middle-class societies or, on the contrary, into increasingly divided class societies. The two levels of analysis are bridged by the concern for social mobility. Here, the question is as to whether change in the employment structure allows forthcoming generations to move to more rewarding jobs than those held by their parents - or whether downward mobility is the more likely outcome. The direction of change has then manifest implications for parties' electoral constituencies and citizens' political preferences.

This chapter strives to shed light on some of these issues by analyzing the pattern of occupational change in Western Europe since I990. It does so by examining the evolution of the employment structure with large-scale microlevel data for Britain, Denmark, Germany, Spain, and Switzerland. The central question is to know what kind of occupations have been expanding and declining over the last two decades: high-paid jobs, low-paid jobs, or both?

Our analysis shows that the five countries under study underwent a process of major occupational upgrading. The only ambiguity concerns the question whether the process is clear-cut or has a polarizing twist to it. The labor market created ample opportunities at the high-skilled end of the occupational structure but made perspectives bleak in the lower-middle range of jobs held by clerks and production workers. Depending on whether low-end services expanded or not, countries find themselves with a more or less polarized 
version of upgrading. In order to make sense of the pattern of occupational change, we examine how the class structure and the sectoral distribution of employment evolved since I990. In parallel, we discuss how it is possible that large numbers of low-skilled jobs vanished over the last two decades without leading to a significant rise in low-skilled unemployment. The key lies in massive educational expansion: Not only low-skilled jobs, but also the low-skilled workers themselves have become more rare over the last two decades.

By analysing occupational change in postindustrial economies, this chapter contributes to the overall framework of this book by shedding light on the demand side constraints of government choices. The introductory chapter to this volume argues that the feasible reform strategies of governments depend among other factors - on the availability of potential sociostructural support coalitions. In this vein, occupational upgrading may alter the political balance of power among different classes and political concerns.

This chapter is structured as follows. Section 4.I presents a snapshot of the long-running debate in the social sciences on occupational change. Section 4.2 moves on to the empirical analysis and presents the data and analytical strategy. Section 4.3 documents change in the employment structure since 1990 and looks at the evolution of the class structure over the same period. Section 4.4 retraces the evolution of low-skilled unemployment and examines the increase in the workforce's educational attainment. Section 4.5 tentatively discusses the social and political implications of upgrading: its potential influence on social inequality and political preferences. Section 4.6 concludes with a summary and an outlook.

\section{I. The Debate in the Literature on Occupational Change}

The debate about the direction of occupational change is as old as the social sciences. Karl Marx, and Marxists after him, held a deeply pessimistic view of the impact of capitalism on the employment structure. Employers were expected to use technology in the struggle between antagonistic classes as a means to fragment work tasks, reduce work autonomy, and increase supervision. Workers would become deskilled and the occupational structure downgrade as self-employed artisans were gradually transformed into wage labor, craft workers into machinists, and clerks into operatives (Braverman I974; Wright and Singelmann I982).

This gloomy expectation contrasts with the optimistic view of Industrialism that North American social scientists developed in the postwar decades partly as a response to Marxist immiseration theory (Kerr et al. I960; Blauner I964). Industrial society and its corollary of a rationally developed technology were seen as leading to growing differentiation within the workforce and hence to an increased demand for skilled labor. From the late I960s onward, industrialism gives way to the theory of postindustrial society and the expectation that 
economic activity would be dominated by knowledge workers (Fuchs I968; Bell I973). Scientific progress and service sector expansion were expected to increase the need for professional and managerial expertise constantly at the expense of routine production tasks. In the early I990s, this optimistic account of technology-driven upskilling became widely accepted in economics under the name of skill-biased technological change (SBTC). SBTC posits that technology is complementary to high-skilled labor but substitutes for low-skilled labor (Berman et al. I998). While the occupational structure upgrades, the employment prospects of low-qualified workers deteriorate.

In parallel to the expanding literature on SBTC, several authors maintained that the impact of technology on the employment structure is not stable over time: While electrification and, more recently, computerization had increased the demand for skilled relative to unskilled labor, mechanization in the nineteenth century had shifted employment away from skilled artisans toward unskilled factory workers (Katz I999: 236, Manning 2004: 603). This argument led to the routinization thesis of technological change: The idea is that computers have taken over routine production and clerical tasks - yet these tasks are typically done in intermediate jobs. In contrast, computers cannot substitute for many interpersonal service tasks such as restaurant waiting, caregiving, or cleaning that are done in jobs set at the bottom of the occupational hierarchy. Modern technology may thus complement both high-skilled analytical and low-skilled interpersonal service jobs, but hollow out the middle of the employment structure, occupied by industrial workers and office clerks (Autor et al. 2003).

The polarization argument was already put forward in the I970s and I980s by proponents of dual labor market theories who argued that the workforces were divided into a primary (or internal) segment of well-paid and stable jobs occupied by insiders and a secondary (or external) segment of low-skilled and insecure jobs left to outsiders (Doeringer and Piore I97I; Lindbeck and Snower 1986). This division between a protected core and a vulnerable periphery was explained either by firms' response to technological change (Doeringer and Piore I97I) or by labor market institutions such as job protection legislation and collective bargaining rights (Lindbeck and Snower I986) - a strand of research revived in recent years under the name of dualization (Emmenegger et al. 20I2).

The focus on institutions has the advantage of explaining country differences in occupational change: Unlike technology, institutions vary across economically advanced countries. Institutional accounts such as the varieties of capitalism approach thus expect occupational upgrading to take place in countries with strong vocational training systems, an equal skill structure, and coordinated wage bargaining - typically coordinated market economies such as the German-speaking and Nordic countries. In contrast, the more unequal skill distribution of liberal market economies such as Britain or the United States should translate into a more polarized pattern of occupational change (Tåhlin 2007: 46). 
A key issue in the analysis of occupational change is unemployment. Institutions such as extensive bargaining rights and high minimum wages may channel technological change into occupational upgrading. But if upgrading implies that a growing proportion of low-skilled workers are priced out of the labor market, a new social divide emerges - not based on unequal earnings, but on unequal access to jobs. Countries may thus have the choice between two undesirable outcomes: occupational upgrading at the cost of unemployment or labor market integration of the low-skilled with the drawback of a polarized earnings structure (Krugman I994; Iversen and Wren I998; Scharpf 2000). The central issue of the debate on occupational change thus concerns the prospects that postindustrial labor markets offer to low-skilled workers.

What does the empirical evidence tell us about the pattern of occupational change? From the I960s up to the I990s, three trends have been common to economically advanced countries: first, the phasing out of agricultural employment and the spectacular drop among farmhands; second, the steady decline of manufacturing jobs, most notably among operatives; third, the rise of business, health, and social services, mainly creating jobs for (associate) managers and (semi)professionals (Castells and Aoyama I994; Berman et al. I998; Juhn I999). The seemingly continuous shift away from lower toward higher skilled work is all the more spectacular if one adopts a longer time horizon and accepts the argument that the majority of preindustrial labor was low-skilled, backbreaking, monotonous, and unrewarding (Attewell 1987: 334).

While much of the international evidence points toward occupational upgrading, this consensus view was shattered in the early 2000 s by two studies finding a trend toward polarization in the United States (Wright and Dwyer 2003; Autor et al. 2008). In a large-scale analysis covering four decades, Erik Wright and Rachel Dwyer (2003) document the shift in the American job structure from unequivocal upgrading in the I960s and I970s to relatively even job growth in the I980s and finally to polarization in the r99os. Large employment gains in business services and public administration explain the expansion at the top, whereas retail trade and personal services provided the jobs at the bottom - jobs largely filled by the growing immigrant Hispanic workforce (Wright and Dwyer 2003: 309). As evidence on the American labor market accumulated, a new consensus emerged: The U.S. employment structure had become subject to an unbalanced - polarized - pattern of growth in the I990s, with strong job expansion at the top, stagnant employment in the middle, and small growth in occupations at the bottom (Ilg and Haugen 2000; Autor et al. 2003, 2008; Rehm 2010: $38 \mathrm{I}$ ).

The controversial question is to know to what extent the American pattern of occupational change also applies to Western Europe. Findings are most ambiguous for Britain. In terms of skills, a battery of different measures points to substantial upskilling of the British labor market over the period I986-2006 (Felstead et al. 2007). In contrast, an influential study defining occupations' quality not based on their skill requirements, but their median earnings, finds 
a clear polarizing trend for the period I979-1999 (Goos and Manning 2007). Two occupational groups account for this simultaneous expansion at the extremes: low-paid welfare state occupations such as nursing aides and educational assistants as well as high-paid business service occupations such as consultants, treasurers, and computer programmers (Goos and Manning 2007: I 24).

Polarization does not describe well the evolution of the employment structure in other European countries. Three comparative studies report a tendency toward occupational upgrading in most Western European countries (Fernández-Macías 20I2: I 5, Hurley and Fernández-Macías 2008: I 2, Tåhlin 2007: 7I). Particularly small affluent countries such as Denmark, Sweden, or Switzerland seem to have witnessed a significant and linear upgrading of their employment structure (Åberg 2003: 203, Korpi and Tåhlin 2009: I92, Skaksen and Sørensen 2002; Sheldon 2005). More controversial are findings for Spain and Germany. In Spain, both the number of professionals and - albeit more weakly - that of low-skilled service workers have increased over the last thirty years (Bernardi and Garrido 2008). In Germany, high-paid and high-skilled occupations grew substantially over the r980s and I990s. But at the same time, midrange jobs disappeared more quickly than those at the bottom end of the labor market (Dustmann et al. 2009: 87 I, Spitz-Oener 2006: 262). Unlike the American experience, the German occupational structure may thus have polarized not because low-end jobs expanded - they probably did not - but because intermediary jobs decreased to a greater extent.

This overview suggests that up to the end of the I980s, labor market researchers agreed in their verdict of occupational upgrading. This consensus no longer holds for the period after I990. While the finding of polarization for the United States seems well established, the evidence for Western Europe is inconclusive. Accordingly, this chapter examines these two areas of uncertainty: the pattern of occupational change in Western Europe in the I990s and 2000 .

\subsection{Country Selection, Data, and Strategy of Analysis}

Our empirical analysis focuses on five West European countries: Britain, Denmark, Germany, Spain, and Switzerland. We thus choose the "most similar systems design" (Przeworski and Teune I970) with the objective to compare countries that differ little on a range of explanatory factors such as economic affluence and technological advancement. This makes it more likely that observed changes in the phenomenon to be explained are caused by those explanatory factors by which these countries do differ, notably labor market institutions. Our group of countries provides us with four different sets of institutions governing social policy and the labor market (Esping-Andersen I990): a liberal Anglo-Saxon welfare regime (Britain), a social democratic Scandinavian regime (Denmark), a conservative Mediterranean regime (Spain), and a conservative continental regime (Germany, Switzerland). We select two 
TABLE 4.I. Key features of the data sets used

\begin{tabular}{|c|c|c|c|c|c|}
\hline & $\begin{array}{l}\text { British Labor } \\
\text { Force Survey }\end{array}$ & $\begin{array}{l}\text { Danish Labor } \\
\text { Force Survey }\end{array}$ & $\begin{array}{l}\text { German Socio- } \\
\text { Economic Panel }\end{array}$ & $\begin{array}{l}\text { Spanish Labor } \\
\text { Force Survey }\end{array}$ & $\begin{array}{l}\text { Swiss Labor } \\
\text { Force Survey }\end{array}$ \\
\hline & LFS & EU-LFS & SOEP & EPA & SAKE \\
\hline $\begin{array}{l}\text { Period } \\
\text { covered in } \\
\text { study }\end{array}$ & I99I-2008 & I992-2007 & I990-2007 & I990-2 & I99I-2008 \\
\hline $\begin{array}{l}\text { Sample size, } \\
\text { early I990s }\end{array}$ & 54,760 & 10,965 & 7,977 & 58,582 & 8,490 \\
\hline $\begin{array}{l}\text { Sample size, } \\
\text { end of } \\
\text { 200os }\end{array}$ & $4 \mathrm{I}, 4 \mathrm{O} 2$ & 51,062 & 9,400 & 62,697 & $23,35 \mathrm{I}$ \\
\hline $\begin{array}{l}\text { Information } \\
\text { on } \\
\text { occupation }\end{array}$ & $\begin{array}{l}\text { soc90 3-digit } \\
\text { soc2000 } \\
\text { 3-digit }\end{array}$ & $\begin{array}{l}\text { isco } 88 \\
2 \text {-digit } \\
+ \text { nace } \\
\text { industry }\end{array}$ & $\begin{array}{l}\text { isco } 88 \\
4 \text {-digit }\end{array}$ & cno94 & $\begin{array}{l}\text { isco } 88 \\
4 \text {-digit }\end{array}$ \\
\hline $\begin{array}{l}\text { Earnings } \\
\text { included }\end{array}$ & Yes (after 93) & No & Yes & No & Yes \\
\hline $\begin{array}{l}\text { Other } \\
\text { database } \\
\text { used for } \\
\text { earnings }\end{array}$ & No & EU-SILC & No & $\begin{array}{l}\text { CIS I989, } \\
\text { I990, } \\
2006\end{array}$ & No \\
\hline
\end{tabular}

Note: *Our samples include individuals aged I 8 to 65 years who spend at least 20 hours per week in employment.

continental countries to account for the fact that this group of welfare regimes is both largest and internally most heterogeneous. For these five countries, changes in the occupational structure are examined for the two decades since German reunification, the period between I990/I and 2007/8. The two cutoff points constitute the end of long cyclical upswings that were then followed by OECD-wide recessions (I99I-I993 and 2008-2010).

Our empirical analysis is based on large-scale microlevel data sets that contain detailed information on individuals' occupation, earnings and education: the national labor force surveys for Britain (UK-LFS), Spain (EPA), and Switzerland (SAKE); the Danish labor force survey stemming from Denmark's cooperation with Eurostat (EU-LFS); and the German Socio-Economic Panel (SOEP). Danish EU-LFS, German SOEP, and Swiss SAKE are annual surveys, whereas Spanish EPA and - beginning in I993 - British LFS are carried out on a quarterly basis. For these two surveys, we choose the spring quarter. Table 4.I gives an overview of the key features of these datasets.

We examine occupational change with the analytical strategy developed by Erik Wright and Rachel Dwyer (2003), which is based on the following three steps. First, we restrict our sample to people aged I 8 to 65 years who spend at least twenty hours per week in paid employment. For these individuals, occupations are distinguished as precisely as possible given the data at hand 
(isco88 at the four-digit level or comparable codes). Occupations containing fewer than ten individuals reporting wages are merged with similar occupations to increase the accuracy of our estimates. Since occupations are coded at a more aggregated level in the Danish survey, we combine them with information on the economic sector in order to obtain a more fine-grained measure of occupations. ${ }^{\mathrm{I}}$ Depending on the country, we distinguish among 108 (Denmark), I 20 (Spain), I45 (Germany), I6I (Switzerland), and I7 I (Britain) different occupations.

Second, we determine an occupation's quality on the basis of its median earning - in our view the most consequential and most reliably measurable indicator of what is a good or bad job. We thus equate occupational upgrading with an expansion of occupations with a comparatively high median earning at the expense of occupations with a low median earning. ${ }^{2}$

Third, once we have calculated the median earning of each occupation over the period of interest, we rank-order the occupations from the lowest- to the highest-paid. These rank-ordered occupations are then grouped into five equally large quintiles, containing as close as possible to 20 percent of total employment at the beginning of the period under study. The bottom quintile I thus holds the 20 percent of employment in the occupations with the lowest median earnings and the top quintile the 20 percent of employment in the occupations with the highest median earnings. The occupational hierarchy looks surprisingly similar in the five countries under study. Sales assistants, waiters, and farmhands are found in the bottom quintile $\mathrm{I}$, bricklayers and truck drivers in the lower-middle quintile 2 , secretaries and machine mechanics in the middle quintile 3 , nurses and police officers in the upper-middle quintile 4 , and senior officials, computer professionals, and doctors in the top quintile 5 .

These five quintiles constitute the building block of our analysis: We determine the pattern of occupational change on the basis of how occupations in

\footnotetext{
Unlike Wright and Dwyer (2003), we explicitly integrate the industry-part of an occupation only for Denmark. For the other four countries, information on the sector of employment (industry) is only used for a few large and indeterminate occupations such as senior officials, managers, secretaries and elementary occupations in the Swiss database and business owners, mid- and low-rank office clerks, operators of mobile machinery, truck drivers and cleaners in the Spanish dataset.

2 An occupation's median earning is calculated as the average of its standardized hourly median earning at the beginning and end of the period under study, weighted by the number of individuals employed in the occupation at a given moment. The Danish EU-LFS and the Spanish EPA surveys do not include information on earnings. For Denmark, we determine occupations' median earnings based on combined data stemming from the three Danish EU-SILC surveys 2004, 2005 and 2006. The Danish case is particular in our analysis insofar as occupations' rank-ordering (based on their median earnings) reflects the situation at the end of the period under study. For Spain, we calculate occupations' median earnings by relying on three surveys performed by Spain's Centre for Sociological Research (I989, I990, 2006). The I990 survey was combined with the I 989 survey to provide single estimates of occupational earnings for the beginning of the period analyzed. These calculations were carried out by Jorge Rodriguez Menes at the University Pompeu Fabra, Barcelona.
} 


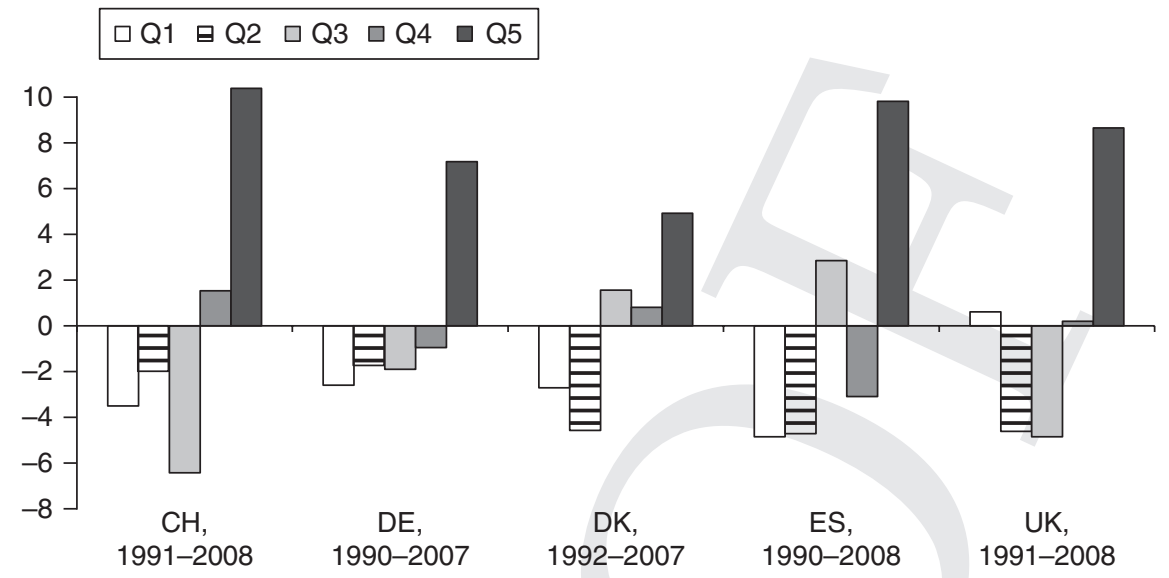

FIGURE 4.I. Relative employment change in job quality quintiles (in percentage points). QI stands for quintile I, which held - at the beginning of the period under study - the 20 percent of employment in the occupations with the lowest median earnings. Q5 stands for quintile 5 , which comprised - at the beginning of the period under study - the 20 percent of employment in the occupations with the highest median earnings.

(The analyses for Spain were generously provided by Jorge Rodriguez Menes, University Pompeu Fabra, Barcelona)

these quintiles evolve in terms of employment. Rather than representing the current distribution of jobs, we thus measure net change by taking into account both job destruction and job creation (for more details on the analytical strategy, see Oesch 2013: 37-42).

\subsection{Empirical Evidence of Occupational Change since 1990}

What has occupational change looked like over the last two decades? Figure 4.I shows that in all five countries under study, employment expanded most at the top of the occupational hierarchy. The occupations set in quintile 5 increased their employment share by 5 percentage points in Denmark (from 20 to 25 percent), by 7 in Germany, by 9 in Britain, and even by ro percentage points in Spain and Switzerland. While employment tended to decrease everywhere in the lower half of the occupational hierarchy, there is substantial cross-country variation. In relative terms, Germany and Spain witnessed the largest job losses in the lowest-paid occupations of quintile I, Denmark in quintile 2, and Britain and Switzerland in the middle quintile 3.

The hypothesis of occupational downgrading can clearly be rejected for the period under study. On the contrary, for Germany and Spain the evidence points toward unambiguous upgrading. The same finding applies to Denmark and Switzerland - although midrange jobs declined somewhat more than low-end jobs. In contrast, results for Britain suggest a pattern of polarized upgrading 
with very strong employment growth at the top of the occupational hierarchy, substantial losses in the middle, and modest growth in the bottom-end quintile. Britain's pattern of occupational change closely resembles that found for the polarizing U.S. employment structure over the I990s (Wright and Dwyer 2003; Autor et al. 2008).

The evidence presented earlier suggests that West European labor markets have created a disproportionate share of job opportunities in high-paid occupations of quintile 5 and thus provided labor market entrants with improving occupational prospects over the last two decades. Intergenerational mobility should thus have risen as older birth cohorts working in menial occupations leave the labor force and retire, while younger generations enter the labor market and take on more qualified occupations. We examine this hypothesis by comparing how age cohorts were distributed across quintiles in I990/I and $2007 / 8$. For this reason, we distinguish four age cohorts $(25-29,30-34$, $35-39,40-44$ years), compute the distribution across quintiles of workers in a given age cohort in I990/I and 2007/8, and then calculate relative change in employment across quintiles between I990/I and 2007/8 for the same age cohort.

The results are shown in Figure 4.2 for four countries (these analyses were not run for Spain). The most interesting finding concerns the two youngest cohorts no longer in full-time education, +workers aged 25-29 and 30-34 years. Everywhere, workers in these two age brackets were much more likely to obtain a job in a top-end occupation of quintile 5 in $2007 / 8$ than had been the case for young cohorts in I990/I. Young people thus were, on average, entering the labor market in more advantageous occupations in the mid-200os than in the early I990s. Occupational change over the last two decades provided succeeding cohorts with greater opportunities for upward mobility. Yet Figure 4.2 also reveals that age cohorts did not experience a linear pattern of occupational upgrading. In the four countries analyzed, young workers were in $2007 / 8$ both more likely to have a job in the top-end quintile 5 and in the bottom-end quintile I than were young workers in I990/I. In other words, entering cohorts in the mid-20oos strongly expanded their relative employment in well-paid occupations of quintile 5 at the expense of the intermediate quintiles, but employment in the low-end quintile I also increased moderately (except in Switzerland). Moreover, the largest decline of employment opportunities over time occurred everywhere in the two lower-middle quintiles 2 and 3 . The rise in occupational polarization of successive cohorts is particularly marked in the United Kingdom, but also evident for Germany and, to some extent, Denmark and Switzerland.

What did occupational change look like in terms of class locations? We examine this issue by using a detailed measure that discriminates hierarchically between more or less privileged employment relationships and horizontally between different work logics (see Oesch 2006). Combining the two dimensions provides us with the eight-class schema shown in Table 4.2, which reveals 

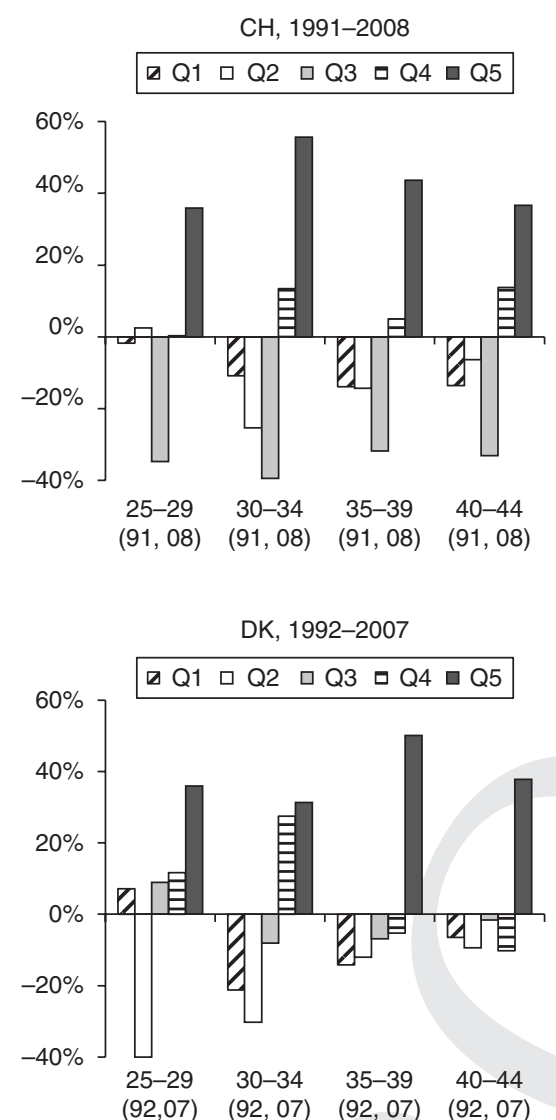
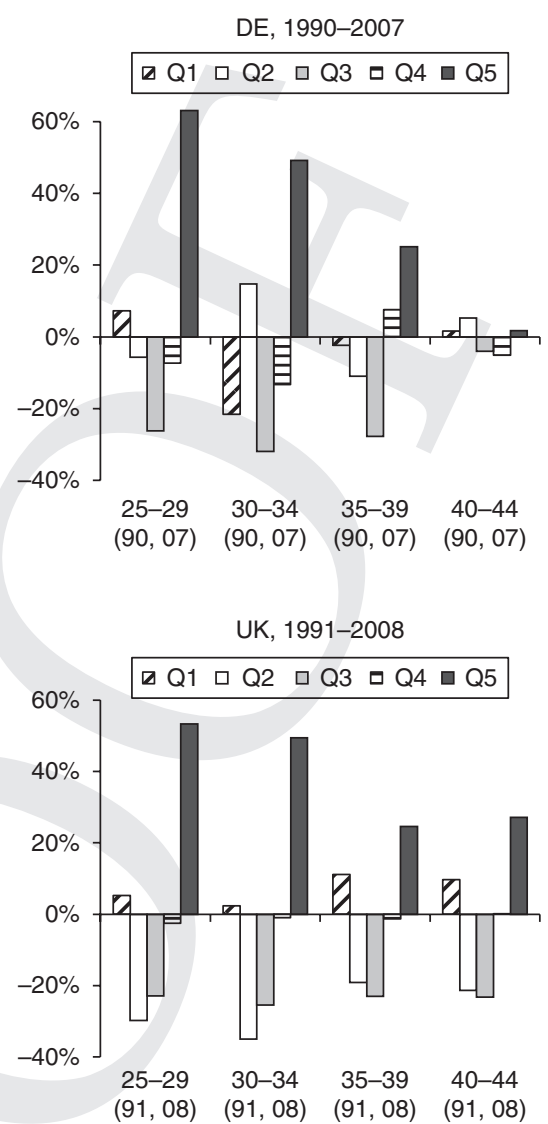

FIGURE 4.2. Change in the distribution of relative employment across quintiles for identical age cohorts.

Note: vertical columns show for Switzerland that workers aged 25-29 were 36 percent more likely to be employed in quintile 5 in 2008 than were workers aged $25-29$ in I99I

that occupational upgrading was driven by two categories: managers and sociocultural professionals. Together with technical professionals, they constitute the strongly expanding salaried middle class. At the beginning of the I990s, only 32 to 35 percent of the labor force belonged to the salaried middle class, as compared to 42 to 45 per cent at the end of the 2000 s.

In contrast, primarily two categories lost out from occupational change: office clerks and production workers. The former shrank dramatically in Denmark and Switzerland; the latter declined most strongly in Britain and Germany. Since clerks cluster in the middle of the earnings distribution, their decline contributed to the hollowing out of the job structure. In comparison, the decrease among production workers was more evenly distributed across the lowest four quintiles (Oesch and Rodriguez Menes 20II: 524). Production workers, 
TABLE 4.2. Change of workforce in eight occupational classes (share in percentage), I990/I-2007/8

\begin{tabular}{|c|c|c|c|c|}
\hline & $\begin{array}{l}\text { Interpersonal } \\
\text { Service Logic }\end{array}$ & $\begin{array}{l}\text { Technical Work } \\
\text { Logic }\end{array}$ & $\begin{array}{l}\text { Organizational } \\
\text { Work Logic }\end{array}$ & $\begin{array}{l}\text { Independent Work } \\
\text { Logic }\end{array}$ \\
\hline & $\begin{array}{l}\text { Sociocultural } \\
\text { (semi) } \\
\text { professionals } \\
\end{array}$ & $\begin{array}{c}\text { Technical (semi) } \\
\text { professionals }\end{array}$ & $\begin{array}{l}\text { (Associate) } \\
\text { managers }\end{array}$ & $\begin{array}{l}\text { Liberal professionals } \\
\text { and large } \\
\text { employers }\end{array}$ \\
\hline & Medical doctors & Engineers & Administrators & Entrepreneurs \\
\hline & Teachers & Architects & Consultants & Lawyers \\
\hline & Social workers & Technicians & Accountants & Dentists \\
\hline $\mathrm{CH}$ & $\mathrm{II} \rightarrow \mathrm{I} 4$ & IO $\rightarrow$ I I & II $\rightarrow$ I 8 & $3 \rightarrow 5$ \\
\hline $\mathrm{DE}$ & $\mathrm{IO} \rightarrow \mathrm{I} 4$ & $\mathrm{IO} \rightarrow \mathrm{IO}$ & $\mathrm{I} 3 \rightarrow \mathrm{I} 8$ & $I \rightarrow 3$ \\
\hline DK & $\mathrm{I} 5 \rightarrow \mathrm{I} 7$ & $8 \rightarrow 8$ & $\mathrm{II} \rightarrow \mathrm{I} 8$ & $2 \rightarrow 3$ \\
\hline \multirow[t]{5}{*}{ UK } & $9 \rightarrow \mathrm{I}_{3}$ & $8 \rightarrow 8$ & $17 \rightarrow 23$ & $2 \rightarrow 2$ \\
\hline & Service workers & $\begin{array}{c}\text { Production } \\
\text { workers }\end{array}$ & Office clerks & $\begin{array}{c}\text { Small business } \\
\text { owners }\end{array}$ \\
\hline & Assistant nurses & Mechanics & Secretaries & Shop owners \\
\hline & Waiters & Carpenters & Receptionists & Independent artisans \\
\hline & Shop assistants & Assemblers & Mail clerks & Farmers \\
\hline $\mathrm{CH}$ & $\mathrm{I} 3 \rightarrow \mathrm{I} 3$ & $24 \rightarrow$ I9 & $\mathrm{I7} \rightarrow \mathrm{IO}$ & I I $\rightarrow$ I I \\
\hline $\mathrm{DE}$ & IO $\rightarrow$ I I & $36 \rightarrow 23$ & I3 $\rightarrow$ I3 & $6 \rightarrow 7$ \\
\hline DK & I $8 \rightarrow$ I 8 & $24 \rightarrow 2 \mathrm{I}$ & $\mathrm{I} 3 \rightarrow 8$ & $9 \rightarrow 7$ \\
\hline UK & II $\rightarrow$ I5 & $25 \rightarrow \mathrm{I} 6$ & $\mathrm{I} 6 \rightarrow \mathrm{I} 2$ & $\mathrm{I} 2 \rightarrow \mathrm{II}$ \\
\hline
\end{tabular}

Notes: Values in gray/ in boxes indicate an employment share in $2007 / 8$ that is 20 percent lower than in I990/I. The shares refer to a target population of individuals aged I 8-65 years who spend at least 20 hours per week in paid employment. Source: Own computation based on the data sets presented in Table 4.I.

service workers, and clerks occupy the twilight zone below the middle class, made up of working-class and lower-middle-class positions. Taken together, the employment share of these three occupational classes decreased from 60 to 47 percent in Germany, from 55 to 48 in Denmark, from 54 to 42 per cent in Switzerland, and from 52 to 43 percent in Britain over the last two decades. As a result, the working- and lower-middle classes combined account today for about the same proportion of the labor force as the salaried middle class in all four countries.

A widely echoed expectation in the political economy literature of the I990s was that employment growth in the age of globalization would have to arise mainly from low-paid private services (e.g., Iversen and Wren I998; Scharpf 2000). Table 4.3 disaggregates occupational change according to the economic sector and shows that, contrary to popular perception, the share 
TABLE 4.3. Employment across sectors in 1990/I and 2007/8 (in percentage)

\begin{tabular}{|c|c|c|c|c|c|c|}
\hline & Agriculture & Manufacturing & Construction & $\begin{array}{l}\text { Sales, } \\
\text { Hotels and } \\
\text { Restaurants, } \\
\text { Personal } \\
\text { Services }\end{array}$ & $\begin{array}{l}\text { Business } \\
\text { Services } \\
\text { Including } \\
\text { Transports }\end{array}$ & $\begin{array}{l}\text { Social Services } \\
\text { and Public } \\
\text { Administration }\end{array}$ \\
\hline $\mathrm{CH}$ & $4 \rightarrow 4$ & $24 \rightarrow \mathrm{I} 8$ & $7 \rightarrow 7$ & $25 \rightarrow 22$ & $22 \rightarrow 25$ & I8. \\
\hline $\mathrm{DE}$ & $4 \rightarrow \mathrm{I}$ & $37 \rightarrow 27$ & $8 \rightarrow 6$ & $\mathrm{I} 4 \rightarrow \mathrm{I} 8$ & $\mathrm{I} 3 \rightarrow \mathrm{I} 8$ & $23 \rightarrow 30$ \\
\hline DK & $5 \rightarrow 3$ & $2 \mathrm{I} \rightarrow \mathrm{I} 6$ & $6 \rightarrow 7$ & $32 \rightarrow 20$ & $12 \rightarrow 20$ & $24 \rightarrow 32$ \\
\hline ES & $12 \rightarrow 4$ & $23 \rightarrow \mathrm{I7}$ & $\mathrm{IO} \rightarrow \mathrm{I} 3$ & $\mathrm{I} 7 \rightarrow \mathrm{I} 8$ & $27 \rightarrow 29$ & II $\rightarrow 20$ \\
\hline UK & $2 \rightarrow 2$ & $27 \rightarrow \mathrm{I6}$ & $9 \rightarrow 9$ & $20 \rightarrow I 6$ & $20 \rightarrow 26$ & $22 \rightarrow 32$ \\
\hline
\end{tabular}

Notes: Values in gray/ in boxes indicate an employment share in $2007 / 8$ that is 20 percent lower than in I990/I.

Source: Own computations based on the data sets presented in Table 4.I; Jorge Rodriguez Menes for Spain. The sample has been restricted to individuals aged I 8-65 years who work at least 20 hours per week.

of employment in private consumer services such as retail trade, restaurants, and hotels decreased (in Denmark, Britain, or Switzerland) or increased very little (in Germany and Spain). While private consumer services stagnated and manufacturing continued to lose jobs in all countries, strong employment growth took place in two areas: in social services mainly set in the public sector and in business services mainly set in the private sector (IT and communication, banking and real estate). This pattern of sector shifts also explains why the problem of stagnant productivity in services (known as "Baumol's disease") is overstated: Growth has taken place in highly productive service sectors, among computer programmers and legal consultants, rather than among domestic aides and waiters.

Where does the tendency toward polarization originate? Not from McJobs in retail trade and restaurants, but from social services. Jobs in health care, social work, and education expanded not only at the top of the employment structure, but - albeit to a lesser extent - also at the bottom end. Growth of social services in the low-end quintile I was not only significant in the United Kingdom, but also in Denmark and Spain. In the United Kingdom, polarization of the occupational system is driven by the evolution in social service jobs, which were created in great numbers both at the top and at the bottom, but not in the middle of the employment structure (Oesch and Rodriguez Menes 20II: 526).

\subsection{Upgrading at the Cost of Unemployment?}

The upgrading thrust may not warrant excessive optimism if it occurs at the cost of unemployment - if the low-skilled have simply been pushed out of the labor market. In this case, governments face a difficult trade-off: They can protect their wage structure and hence smother the growth of low-wage services. 
Thereby, they limit wage inequality and achieve occupational upgrading but have to cope with growing unemployment among the low-skilled who are priced out of the labor market (Krugman 1994; Scharpf 2000).

The trade-off between upgrading and full employment should play itself out at the labor market's bottom end. Accordingly, we examine in Table 4.4 low-skilled workers' unemployment rates. ${ }^{3}$ They are averaged over five-year periods in order to smooth out the business cycle effect. Still, low-skilled unemployment closely trails the cyclical evolution of general unemployment - when general unemployment rose or fell, low-skilled unemployment followed suit. Over the period under study, low-skilled unemployment thus increased substantially in Germany and more moderately in Switzerland, while it gradually declined in Britain and Denmark prior to the global financial crisis in 2008. In Spain, low-skilled unemployment embarked - like general unemployment - on a spectacular roller-coaster journey, with a steep hike in the early I990s, an even more massive fall between 1995 and 2007, and a staggering rise thereafter.

Did occupational upgrading ruin low-skilled workers' labor market prospects? Table 4.4 throws doubts on this gloomy expectation: In 2008, the low-skilled unemployment rate was below 7 percent in Britain, Denmark, and Switzerland - and thus moderate despite an ongoing process of occupational upgrading. Most notable is the evolution in the two small countries in our sample, Denmark and Switzerland. Neither country witnessed a polarization of its employment structure. In effect, job losses in the bottom-end quintile I were substantial in both countries $(-42,000$ jobs in Denmark between 1992 and 2007, -53,000 in Switzerland between I99I and 2008) - yet low-skilled unemployment did not skyrocket. On the contrary, in Denmark it continuously declined over the I990s and 2000 s and fell below 4 percent prior to the Great Recession.

Unemployment rates paint a too-optimistic picture of low-skilled individuals' employment opportunities if involuntary labor market withdrawal takes other forms such as disability or early retirement. We check this possibility by computing in Table 4.4 the low-skilled employment rate, which measures the proportion of low-skilled working-age adults (aged 25 to 64 years) who are in gainful employment - and are thus neither unemployed nor economically inactive. Table 4.4 shows that over the last two decades, Denmark and Spain succeeded in significantly raising the employment rate of their low-skilled working-age population. In Britain, the low-skilled employment rate remained at a comparatively high level of 65 percent between 1997 and 2008. In contrast, Germany and Switzerland's low-skilled employment rate rose and fell in unison with the business cycle, all the while showing a slight downward trend. Interestingly, country differences became smaller over time but did not

\footnotetext{
3 The low-skilled are defined as having an educational attainment of lower-secondary school or
} less, that is no more than 9 to Io years of formal education (ISCED levels o-2). 
TABLE 4.4. Low-skilled unemployment and employment rates averaged over five-year periods (in percentage)

\begin{tabular}{|c|c|c|c|c|c|c|c|c|}
\hline & \multicolumn{4}{|c|}{ Low-Skilled Unemployment Rate } & \multicolumn{4}{|c|}{ Low-Skilled Employment Rate } \\
\hline & $9 I-95$ & 96-०o & OI-O5 & $06-08$ & $9 I-95$ & 96-oo & OI-O5 & $06-08$ \\
\hline $\mathrm{CH}$ & 4 & 6 & 6 & 7 & 68 & 68 & 67 & 66 \\
\hline DE & I I & I 5 & I7 & I 8 & 53 & 48 & $5 \mathrm{I}$ & 50 \\
\hline DK & I I & 8 & 7 & 4 & 62 & $6 I$ & 62 & 65 \\
\hline ES & I 8 & I7 & I I & I0 & 47 & 50 & 57 & 60 \\
\hline UK & I 2 & Io & 6 & 6 & $6 \mathrm{I}$ & 65 & 66 & 65 \\
\hline
\end{tabular}

Note: The low-skilled employment rate measures the employment-to-working-age population ratio for low-skilled individuals aged 25-64 years. Low education is defined as ISCED levels o-2 (preprimary, primary, and lower secondary education).

Source: OECD, Education at a Glance Database.

disappear. Britain, Denmark, and Switzerland feature substantially higher employment rates among the low-skilled than Germany and Spain.

Table 4.4 points out two interesting conclusions. First, there is no clear-cut trend toward reduced labor market participation of low-skilled adults in the five European countries under study. Rather than showing a secular decline, low-skilled workers' employment rates reflect the underlying business cycle, strongly expanding during Spain's labor market boom I995-2007 and contracting during Germany's economic recessions. Second, countries with comparatively low wage inequality and a strong trend toward upgrading such as Denmark and Switzerland seem at least as successful in integrating low-skilled workers into the labor market as Britain, where high wage inequality and a polarizing occupational structure should have stimulated the creation of low-paid jobs to a greater extent than elsewhere. Evidently, the trade-off argument continues to fare badly in empirical scrutiny (see also Nickell and Bell I996: 307; Card et al. I999: 870; Glyn 2001: 701; Bosch 2009: 349).

How is it possible that large numbers of low-skilled jobs have vanished over the last two decades without leading to a significant rise in low-skilled unemployment or to a massive drop in low-skilled workers' labor market participation? ${ }^{4}$ The answer is strongly related to the evolution of skill supplies: Not only have jobs for the unqualified become more rare, but so have the unqualified people themselves. Goldin and Katz (2007) argue that labor markets evolved in the twentieth century as the result of a race between education and

\footnotetext{
4 Nor has there been a significant widening in lower-tail wage inequality. Over the period I990-2005, the gap between the median wage and the wage at the Ist decile (p5o/pIo) seems to have remained stable in the majority of OECD countries, notably in Britain, Switzerland and the U.S. (OECD 2007: I 28). An exception is Germany where lower-tail wage inequality has been on the rise since the mid-I990s (Antonczyk et al. 2009: 9).
} 
technology: Permanent technological change increased firms' demand for skills and massive educational expansion increased workers' supply of skills. In this race, educational advance seems to have kept up with technological progress in the countries under study.

In Western Europe, educational expansion began in earnest in the I950s with the strong growth of educational enrollments in upper secondary schooling. It took up speed in the following decades when universities and technical colleges were opened to significantly larger sections of the population. This process continued over the last two decades. Between I990 and 2008, the proportion of the labor force with a tertiary degree increased from less than a fourth to more than a third in Britain, Denmark, and Switzerland and from less than a fifth to a fourth in Germany and Spain. In parallel, the share of the workforce without upper secondary schooling declined everywhere and dropped below 20 percent in Britain, Denmark, and Spain and below I 5 percent in Germany and Switzerland. ${ }^{5}$ Moreover, statistics of educational attainment probably underestimate the real extent of upskilling, as the qualifications of those with upper secondary schooling - still the majority of the population increased at the level of both general education (A-Levels and Abitur instead of O-levels and Mittlere Reife) and vocational training (longer and more qualifying apprenticeships).

A more difficult question is to know whether this upward shift in skills has taken place in unison with occupational change. Causality between educational expansion and occupational upgrading may run in both directions. On the one hand, industrial automation, the spread of computers in services, and the massive decline in semiskilled jobs provided incentives for young people to stay on in school longer and invest in their education. On the other hand, abundant skill supplies may also have led employers to adapt their production techniques and to create high-skilled jobs in order to benefit fully from the educational profiles available on the labor market.

A counterfactual analysis run on our data suggests that the pattern of occupational change predicted on the sole basis of skill evolution closely mirrors the observed pattern (Oesch and Rodriguez Menes 20I I: 52 I). Educational expansion and occupational upgrading seem to have gone hand in hand in all five countries. However, the correspondence between educational upskilling and occupational upgrading is stronger in Denmark, Germany, and Switzerland, where vocational training dominates, than in Britain and, above all, Spain, where educational expansion over the last two decades was particularly strong and outpaced occupational upgrading.

In effect, the skill evolution in Britain and Spain would lead us to expect a larger decline in low-paid occupations than the one observed in Figure 4.I. One key element is immigration: Both Britain and Spain experienced strong surges in immigration between the late I990s and the crisis of 2007/8. While immigrants

\footnotetext{
5 Own computations based on data shown in Table 4.I.
} 


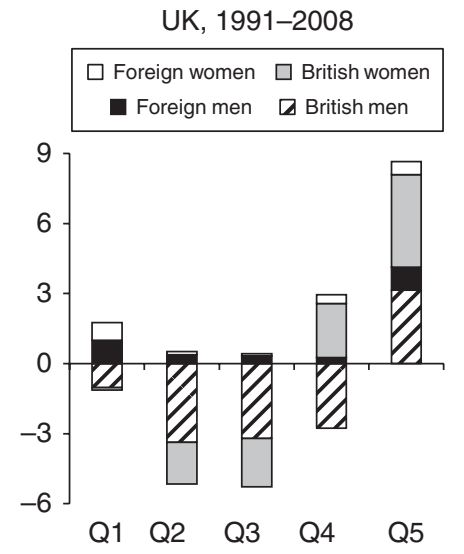

ES, 1990-2008
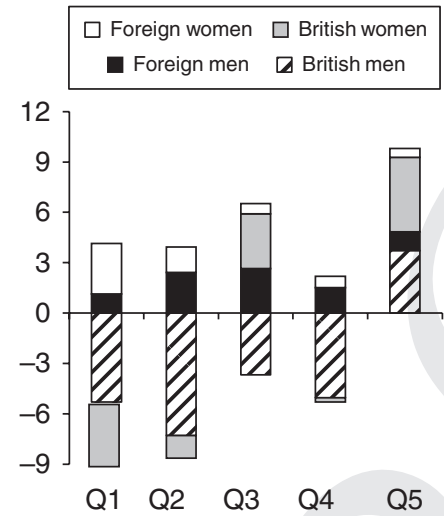

DE, 1990-2007

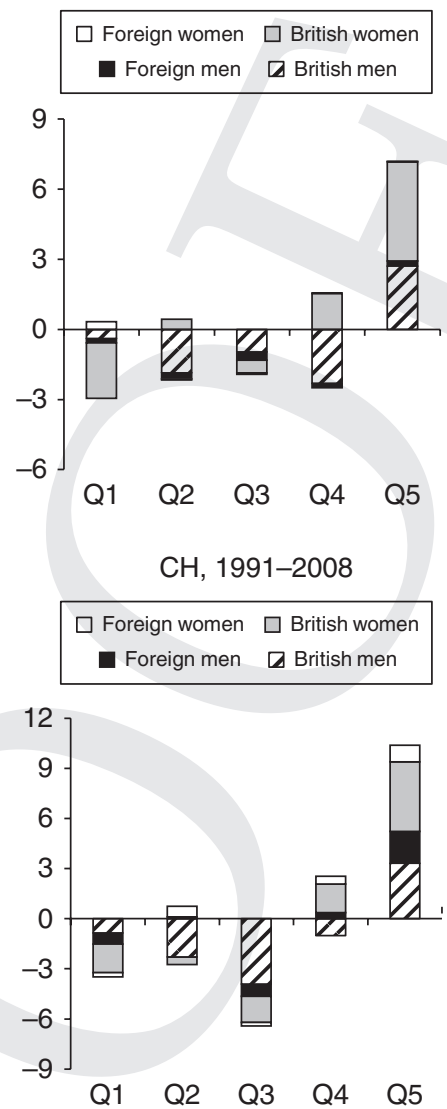

FIGURE $4 \cdot 3$. Contribution of nationality-gender groups to the pattern of occupational change (relative change in employment in percentage points).

were mostly low-skilled in Spain, they had a bimodal skill distribution in Britain, with disproportional shares among both the least and the most highly educated (OECD 2008: 83). We analyze the role of immigration by disaggregating relative change in employment for four nationality-gender groups: national women, foreign women, national men, foreign men. Figure 4.3 shows the contribution that these four groups make to the observed pattern of occupational change for Britain, Germany, Spain, and Switzerland (results for Denmark not shown here). Two findings are noteworthy.

First, occupational upgrading between the early I990s and the late 2000 s was strongly fostered by national women. While the share of national women working in the low-paid jobs of quintile I decreased considerably, their proportion expanded massively in quintile 5 in all five countries under 
study. Accordingly, women's catch-up process in educational attainment has everywhere translated into higher occupational attainment.

Second, in Britain and Spain expansion in low-paid occupations of quintile I was exclusively due to job growth among foreign workers. In the United Kingdom, the relative employment decline in quintile I among British men and women was overcompensated by the employment rise among foreign men and women. In Spain, foreign workers - above all, women - also increased their employment in quintile I, whereas relative employment among Spanish men and women strongly fell. In Germany and Switzerland, employment shifts were similar for nationals and foreigners.

The U-shaped skill profile of immigration contributed to occupational polarization in Britain. Comparable to Hispanics in the United States, East European immigrants in Britain supplied the manpower necessary to fill the gaps at the bottom end of the labor market (Wright and Dwyer 2003: 308; Oesch and Rodriguez Menes 20II: 53I). Without the large surges in immigration between the late I990s and the mid-2000s, Britain and Spain would probably have experienced a stronger trend toward occupational upgrading simply because employers would not have found as abundant a labor supply for low-paid jobs.

\subsection{What Implications for Inequality and Politics?}

What are the social and political implications of an occupational structure that expands massively at the top, declines in the middle, and stagnates at the bottom end? Clearly, the labor market creates new opportunities at the high-skilled end of the occupational structure, but makes perspectives in the (lower) middle range of jobs bleaker. Bleaker prospects primarily affect clerks and production workers. Their numbers have dropped and led to a thinning out of the twilight zone between the working and the middle class. Secretaries, tellers, craft workers, or plant operators are all occupations at the fringes of the lower-middle class that - while not requiring high levels of education - used to secure middle-range incomes and a steady rise in living standards. Today, people in these occupations do not face a bright future. In the case of plant closure, organizational downsizing, or career interruptions, they are exposed to a serious risk of social downgrading.

The drop in clerical and manufacturing jobs also means that workers who have limited education have fewer opportunities for upward mobility. Unlike the situation prevailing when industrial plants and organizational bureaucracies expanded, it probably has become more difficult for people working in the least-paid jobs to move up in the employment structure. Large industrial firms, financial conglomerates, or public utilities in postal services, telephone, and energy no longer provide ample job opportunities for semiskilled workers. Without higher education (advanced vocational degrees or schooling at the tertiary level), it probably becomes increasingly difficult to secure a job - or to 
move to a senior position over the career - that provides a middle-class lifestyle (Wright and Dwyer 2003: 322).

Ironically, future demand for low-skilled jobs may depend on the expansion among managers and professionals. Personal services such as cleaning, home delivery, babysitting, or private security are determined by the geographic proximity of wealthy customers and the extent of income inequality: The greater the difference between the customers' purchasing power (the wealthy individual's income) and the price of the personal service (the poor individual's wage), the greater the demand (Manning 2004: 588). Combined with increasing marital homogamy (see Chapter 6 by Gøsta Esping-Andersen, this volume) and the time constraints afflicting dual-earner households, occupational upgrading may thus generate the consumer demand for services supplied by low-paid workers.

In this context, Wright and Dwyer (2003:323) raise the question whether polarization in the U.S. labour markets leads to a rise of master-servant relationships - to a new cultural reality of social inequality where a growing share of the people at the bottom provide personal services to the people at the top: cleaning their house, ironing their clothes, delivering their groceries, babysitting their children. Table 4.2 does not show a significant increase among interpersonal service workers except in Britain. A possible explanation may be that higher wage floors - set directly by collective agreements and indirectly by the welfare state - make McJobs economically less viable in Denmark, Germany, and Switzerland than in Anglo-Saxon countries. However, since our analysis only includes people spending at least twenty hours per week in formal employment, our results are likely to be lower-bound estimates. Part-timers working few hours and illegal immigrants make up a sizable (and probably growing) share of the workforce in low-end personal services.

What are the political implications of unbalanced occupational upgrading? To begin with, there is the paradox that class divisions deepen, but class mobilization weakens (Kohli forthcoming). Most available indicators suggest that the gap in earnings between the salaried upper-middle classes and the lower classes has widened over the last two decades. At the same time, the political mobilization of social class - notably of the working class, not the very upper class (Hacker and Pierson 2010) - has dwindled, be it in terms of strike activity, wage bargaining, or collective organization. A central piece in this puzzle is the decline among production workers. Once the backbone of labor parties and trade unions, the industrial working class shrank by another third since the early I990s and today accounts even in Germany - the most industrial West European country - for less than a fourth of the labor force (see Table 4.2). Outside the Scandinavian countries, union movements have been incapable of substituting their declining core constituency of male blue-collar workers with female employees in expanding social services, education, and health care. The results are lower union density, less inclusive collective bargaining, and 
increasingly flexible employment relationships (Bosch 2009; see also Chapter 9 by Anke Hassel, this volume, on the decline of trade unions).

In terms of political preferences, the implications are more difficult to grasp. Occupational upgrading has contributed to the increasing heterogeneity of the social structure, adding to the sectoral heterogeneity that is shown in Chapter 2 of this volume. More fundamentally, it has provided new opportunities for some groups, while making life more difficult for others. The winners benefited from the opening up of tertiary education to new social categories and the growth of highly qualified positions in the professions and management. Thanks to the democratization of higher education and the expansion of business and welfare services, large proportions of the population have obtained comfortable positions within the salaried middle class. The losers are primarily found among blue-collar workers, semiskilled clerks, personal service workers, owners of small stores, and independent artisans who have lost out from both educational and occupational upgrading and find themselves at the gradually less populated lower end of the social structure. The evolution toward a more skill-intensive and competitive service economy has worsened their job and mobility prospects. In addition, they are more vulnerable to economic openness than the high skilled, either because their jobs can be offshored, or because the immigrant inflow in their occupations tends to be larger (see Chapter 5 by Dancygier and Walter, this volume).

This widening gap in life chances spills over into political and partisan preferences (see Chapter 8 by Häusermann and Kriesi, this volume). The winners of upgrading have embraced libertarian and universalistic values - among others strongly supporting parties of the New Left, notably the Greens - and are firm supporters of liberal democracy. In contrast, the losers have disproportionately rallied around right-wing populist parties (Kitschelt 2007; Kriesi et al. 2008; Oesch 20I2). This has happened in part because deindustrialization and educational expansion eroded working-class culture and organizations, leaving an organizational void readily filled by right-wing populist movements. The populist Right's angry resistance to cultural change, its solitary opposition against the political elites, and its pointed defense of national preference seems to strike a chord with the losers. In West European countries with a sizable right-wing populist party, production and service workers form the core of the party's electorate (Bornschier and Kriesi 20 I2; Ivarsflaten 2005; Oesch 20I2).

The cleavage between losers and winners of social modernization overlaps with a new geographical divide of which we only see first contours. The winners - high-paid dual-earner couples working in management and the professions - primarily expand in the metropolitan centers and transform European cities into increasingly exclusive commercial and residential areas. West European capitals are thus undergoing a much faster process of occupational upgrading than the suburbs, small towns, or countryside. A prime example is London. In I98I, inner London used to be more working class than the rest of England, but in $200 \mathrm{I}$ it had a much greater concentration of 
the middle and upper classes than outer London, the South East, or the rest of England (Butler et al. 2008: 77). In Paris, the expansion of the professional middle classes was even more pronounced. Its metropolitan area is increasingly segmented into three socially distinct spaces: The salaried upper-middle classes live in the cente; the working poor are relegated to the suburban sprawl; and the old (and lower-) middle classes settle in the periurban area of detached houses (Donzelot 2004). A similar evolution can be observed in Southern European cities such as Barcelona, Lisbon, Madrid, Milan, or Rome, where the rising concentration of the upper-middle classes in the center contrasts with the peripheral settlement pattern of the working class and notably of immigrants (Arbaci and Malheiros 2010).

\subsection{Conclusion}

In debates about society in the twenty-first century, two notions hold great sway over both the academic and the general public: labor market dualization and the end of the middle class. Both ideas make reference to significant phenomena - the destandardization of employment and the increase in income inequality. However, another evolution in the labor market, namely, the pervasive upgrading of the occupational structure, has affected our societies to a much greater extent. This chapter examined how the occupational structure of five advanced industrial democracies evolved since the beginning of the I990s and produced four main findings.

First, the different labor force surveys make a clear case for occupational upgrading. Employment expanded much faster in high-paid occupations in management and the professions than in mid- and low-paid jobs in production, menial services, and the back office. This shift in employment has fundamentally redrawn - and is still redrawing - the face of European societies. As professional and managerial jobs expanded at the expense of the lower-middle class and the industrial working class, the class structure moved upward in all five countries under study. Contrary to what newspapers like to claim, technological change has not eroded the middle class, but the ranks of production workers and office clerks.

Second, occupational upgrading did not lead to major disequilibria in the labor market because it was accompanied by a major increase in the educational attainment of the workforces. By supplying greater numbers of mid- and high-educated school leavers, educational systems successfully met the increasing skill demands of firms. Occupational upgrading thus did not occur at the cost of low-skilled workers' labor market prospects: Their employment rates did not significantly decline in any of the five countries studied. The growth in the numbers of tertiary-educated people and the parallel decline in those of people with only compulsory schooling explain why low-paid jobs could decline without causing a rise in low-skilled unemployment. Moreover, in countries with strongly growing low-end services such as Britain, Spain, or the 
United States, the large inflow of low-skilled immigrants provided the labor supply to fill these jobs.

Third, unlike studies on the American labor market, our analysis of European surveys produces, at best, lukewarm support for a trend toward employment polarization. It would be tempting to overplay the result of polarization - because it makes for such a spectacular story (Goos et al. 2009). Yet our data make a much stronger case for occupational upgrading. Keeping this reservation in mind, several elements suggest that polarization may nonetheless become more consequential for the future of European labor markets. To begin with, employment dropped more in intermediary than in bottom-end occupations in Britain and, to a lesser extent, Denmark and Switzerland, as firms' falling demand for production and back-office staff led to a decline in lower-midrange jobs. Moreover, the comparison of age cohorts between the early I990s and the late 2000 s suggests that the employment structure evolved in a j-shaped pattern, with strong job creation at the top of the occupational hierarchy, a decline in the middle and relative stability at the bottom end. In addition, low-skilled workers' employment rates heavily depend on the underlying business cycles; that is, they have been particularly heavily hit by the Great Recession.

Fourth, our evidence does not support the assumption, popular in the early 2000s, that postindustrial economies could only achieve full employment if they opened their wage structure downward and created low-paid service jobs (Krugman 1994; Iversen and Wren 1998; Scharpf 2000). Nothing in our analyses indicates that Scandinavian and Continental European countries need to travel down this desolate road. On the contrary, if governments want to support occupational upgrading, they seem well advised to take action at both ends of the labor market. At the upper end, public investment in tertiary education allows firms to hire high-skilled workers in sufficient numbers and thus to take full advantage of technological advance. At the lower end, a strengthening of upper secondary education - notably vocational training - and the establishment of a minimum wage incite firms to invest in workers' productivity rather than to rely on a stagnant low-wage sector.

The central political implication of unbalanced occupational upgrading whether accentuated by polarization or not - is the relative decline of originally powerful social-structural groups. The trend toward a more skill-intensive and competitive service economy worsened the job and mobility prospects of production workers, semiskilled clerks, owners of small stores, and independent artisans, who find themselves at the gradually less populated lower end of the social structure. As a result of this decline, we observe a decrease of the political clout of the organizations that have defended the interests of these groups in the past, notably trade unions (see Chapter 9), and a gradual shift of the representation of their interests to new organizations, notably the parties of the new populist Right (see Chapter 8). 